\title{
Microbial alteration of stable nitrogen and carbon isotopic compositions of organic matter
}

\author{
Stephen A. Macko* and Marilyn L. F. Estep \\ Geophysical Laboratory, Carnegie Institution of Washington, Washington, DC 20008. U.S.A.
}

\begin{abstract}
An understanding of the interaction between microbes and organic matter can help elucidate the diagenesis of organic materials in sediments. Vibrio harveyi, a marine, aerobic. heterotrophic bacterium, was cultured on individual compounds each containing carbon and nitrogen, i.e. amino acids or amino sugars. When grown on different substrates, the bacteria fractionated the isotopes uniquely. These fractionations were related to the chemical nature of the substrate. Specifically, the $\mathrm{C} / \mathrm{N}$ of the substrate, or the biosynthetic and metabolic pathways of these substances, or both, are important in determining the isotopic composition of the total organism. For example, bacterial nitrogen was enriched in ${ }^{15} \mathrm{~N}$ (up to $22 \%$ ) when the bacterium was cultured on either glutamic or aspartic acid. These amino acids enter the metabolic pathways directly, and the remainder of cellular nitrogen is derived via transamination. When other amino acids, i.e. alanine and serine, enter the microbe, they are immediately deaminated, and free ammonia is then transferred to glutamic acid. Bacteria that have been cultured on alanine or serine are depleted of ${ }^{15} \mathrm{~N}$ by up to $-12 \%$. The results are important in determining isotope effects in respiration and biosynthesis. Moreover, the results could be used to demonstrate that microbes have the potential to alter to a highly variable extent the isotopic composition of organic matter entering the sedimentary record.
\end{abstract}

Key words: carbon isotopes, nitrogen isotopes, bacteria, $\mathrm{C} / \mathrm{N}$ ratios, isotopic fractionation

\section{INTRODUCTION}

Bacterial alteration of biochemical substances is a major process in the early diagenesis of organic geochemicals. Whereas micro-organisms are well known for their ability to alter the isotopic composition of inorganic substrates, e.g. sulfur and nitrogen compounds (Nakai and Jensen, 1964; Chambers and Trudinger, 1979; Miyazaki et al., 1980), and to fractionate carbon and nitrogen isotopes during assimilation and synthesis (Estep et al., 1978; Macko et al., 1982), relatively little is known about the isotope fractionations associated with microorganisms that require organic substances for their growth. Chemical and isotopic determinations of these processes have been confined to studies in natural environments where diverse populations of bacteria have been presented with an array of organic materials as food sources. For these reasons the carbon and nitrogen isotopic compositions of the cellular materials from cultures of a marine, aerobic bacterium have been analyzed to initiate research on isotopic fractionations associated with heterotrophic microbiological activity.

Vibrio harveyi strain B-352 is a marine, aerobic, heterotroph that can grow on a wide variety of individual amino acids or the amino sugar $N$ acetylglucosamine (see Nealson, 1978). These amino-organic compounds provide both the carbon and the nitrogen necessary for cellular growth and biosynthesis.

Heterotrophic bacteria obtain their cellular energy from the generation of high-energy compounds

\footnotetext{
*Present address: Department of Earth Sciences, Memorial

University of Newfoundland, St. John's, Newfoundland A1B 3X5. Canada
}

formed in reactions of the Krebs cycle. For each carbon molecule in an organic compound that completes this cycle, a discrete quantity of biosynthetic energy is produced. Thus, amino acids or sugars with higher carbon numbers will produce more cellular energy per mole of substrate than those with lower carbon numbers. Bacteria growing on amino acids, e.g. with only two or three carbon atoms, must metabolize a greater percentage of these compounds to obtain an energy level and growth similar to those of bacteria utilizing a five- or six-carbon compound.

\section{METHODS}

The organism was obtained from Dr K. H. Nealson, Scripps Institution of Oceanography, University of California, and was cultured on an artificial sea water medium, ASP-2 (Van Baalen, 1962), supplemented with $0.2 \%$ (wt/vol) of the amino compound. An inoculum of cells was cultured on ASP-2 enriched with $0.2 \%$ glycine. Cultures for the experiments were inoculated with $1 \mathrm{ml}$ into $75 \mathrm{ml}$ of fresh media containing the supplementing amino acid. After 2 days, growth occurred with all substrates, and most cultures were harvested after 6-10 days. The growth rate ( $\mathrm{mg}$ dry wt of bacterial cells day ${ }^{-1}$ ) of Vibrio, however, varied accordingly with the substrate amino acid used for the $\mathrm{C}$ and $\mathrm{N}$ source. Moreover, the cell yield (mg dry wt of bacterial cells $\mathrm{mg}$ amino acids metabolized $\left.{ }^{-1}\right)$ also varied depending upon the substrate amino acid. Nitrate was deleted from the medium in half the experiments, as indicated in Table 1.

General techniques for harvesting of the cultures included centrifugation and multiple distilled water 
Table 1. Isotope fractionation of organic substrate by bacteria

\begin{tabular}{|c|c|c|c|}
\hline \multirow{2}{*}{$\begin{array}{l}\begin{array}{l}\text { Nitrogen } \\
+ \text { carbon source }\end{array} \\
\text { Serine }+\mathrm{NO}_{3}\end{array}$} & \multirow{2}{*}{$\frac{\Delta^{1.3} \mathrm{C} t}{-6.3}$} & \multicolumn{2}{|c|}{$\begin{array}{l}\text { Percentage amino } \\
\text { acid utilized }\end{array}$} \\
\hline & & +2.4 & 88.7 \\
\hline Serine & -9.0 & +2.7 & 99.3 \\
\hline Alanine $+\mathrm{NO}_{3}$ & -9.0 & +9.9 & 87.5 \\
\hline Alanine $+\mathrm{NO}_{3} 48 \mathrm{~h} \$$ & -9.1 & +8.2 & 45.4 \\
\hline Alanine $+\mathrm{NO}_{3}^{-72 \mathrm{~h}}$ & -9.0 & +8.4 & 64.3 \\
\hline Alanine $+\mathrm{NO}_{3} 96 \mathrm{~h}$ & -9.0 & +9.6 & 77.5 \\
\hline Alanine $+\mathrm{NO}_{3} 6 \mathrm{~d}$ & -8.6 & +8.9 & 91.5 \\
\hline Alanine $+\mathrm{NO}_{3}^{-} 10 \mathrm{~d}$ & -8.7 & +9.0 & 97.7 \\
\hline Alanine & -9.4 & +.9 .4 & 93.5 \\
\hline d-Alanine $+\mathrm{NO}_{3}$ & -11.3 & +11.1 & 77.8 \\
\hline d-Alanine & -12.9 & +3.1 & 89.7 \\
\hline Threonine + $\mathrm{NO}_{3}$ & -5.9 & +0.3 & 55.6 \\
\hline Glutamate $+\mathrm{NO}_{3}$ & +12.3 & +2.5 & 53.2 \\
\hline Glutamate & +22.3 & +1.0 & 79.5 \\
\hline Glutamate $27 \mathrm{~h}$ & +22.3 & +0.7 & 50.5 \\
\hline Glutamate $41 \mathrm{~h}$ & +21.9 & +0.4 & 59.0 \\
\hline Glutamate $89 \mathrm{~h}$ & +22.1 & +0.3 & 62.7 \\
\hline Glutamate $8 \mathrm{~d}$ & +22.0 & +0.4 & 68.3 \\
\hline Glutamate $10 \mathrm{~d}$ & +22.2 & +0.1 & 80.1 \\
\hline Aspartate $+\mathrm{NO}_{3}$ & +12.6 & +5.2 & 41.3 \\
\hline Aspartate & +12.5 & +4.8 & 61.2 \\
\hline Tyrosine $+\mathrm{NO}_{3}$ & +1.4 & -5.2 & 97.8 \\
\hline Ty̆rosine & +5.7 & -5.5 & 95.4 \\
\hline Proline $+\mathrm{NO}_{3}$ & +2.0 & +1.3 & ND \\
\hline Proline & +0.3 & +0.4 & ND \\
\hline Arginine $+\mathrm{NO}_{3}^{--}$ & +6.5 & -1.6 & 85.0 \\
\hline Arginine & +4.6 & -2.6 & 64.1 \\
\hline$N$-Acetylglucosamine & -0.9 & +4.1 & ND \\
\hline Glycine $+\mathrm{NO}_{3}^{-}$ & +4.0 & +9.0 & 53.4 \\
\hline Glycine & +2.7 & +6.0 & ND \\
\hline
\end{tabular}

$* \Delta^{15} \mathrm{~N}=\delta^{15} \mathrm{~N}$ initial substrate amino acid $-\delta^{15} \mathrm{~N}$ bacterial cellular material.

$\dagger \delta^{1.3} \mathrm{C}=\delta^{1.3} \mathrm{C}$ initial substrate amino acid $-\delta^{1.3} \mathrm{C}$ bacterial cellular material.

$\$$ Amino acids were $l$-enantiomer except alanine.

$\$$ Amount of time (h or d) cultures were grown before harvesting.

Not determined.

rinses to eliminate possible contamination of substrate (Macko et al., 1982). The culture media were refrigerated after centrifugation, and an aliquot was analyzed by ion exchange HPLC (Hare, 1977) to determine the amounts of amino acids remaining in the media. In addition, the excretion of $\mathrm{NH}_{3}$ and of other amino acids different from that of the initial substrate was checked. Ammonia was excreted in all cultures, but the levels of de novo excreted amino acids were at the limits of detection. The isotopic composition of the amino acids used as substrates was measured only before the culture experiments. The medium ASP-2 contains Tris [Tris(hydroxymethyl) aminomethane] as a buffer $\left(1 \mathrm{~g} \mathrm{l}^{-1}\right)$, such that with the added complication of purifying the remaining amino acid after growth, the isotopic composition of the amino acid substrate after culturing was not attempted. Conversion of the organic nitrogen and carbon to gases of suitable purity for stable isotope analysis was accomplished with a Dumas combustion in a quartz sealed tube (Macko, 1981).

\section{RESULTS AND DISCUSSION}

The carbon and nitrogen isotope fractionations of $V$. harveyi are reported relative to the original isotopic composition of the amino acid contained in the medium (Table 1). Generally, the bacterial cells were enriched in ${ }^{13} \mathrm{C}$ relative to the substrate. This enrichment is most likely the result of respiration of organic substances in the Krebs cycle during growth. The product, respired $\mathrm{CO}_{2}$, must be isotopically depleted of ${ }^{13} \mathrm{C}$. Whether the depletion is the result of kinetic isotope effects in enzymatic reactions or preferential loss of light carbon because of isotopic differences among the individual carbon atoms in the compound is unknown. The ${ }^{13} \mathrm{C}$ of bacteria cultured on tyrosine and arginine were distinctly more negative than the substrate. In tyrosine the bacterium may not have been able to metabolize the aromatic ring. and thus it preferentially excreted isotopically distinct carbon atoms.

The nitrogen isotopic compositions of the cells resulted in three classifications of fractionations of the substrate: (1) a large depletion of ${ }^{15} \mathrm{~N}$ in the cells, (2) a large enrichment of ${ }^{15} \mathrm{~N}$ in the cells, or (3) no major difference.

Heterotrophic micro-organisms have extremely active amino acid deaminating enzymes. Amino acids enter into the cell and are deaminated, forming ammonia plus organic acids. The ammonia is fixed into glutamic acid, and this nitrogen is subsequently passed on to most of the protein amino acids, while the organic acid is metabolized via the Krebs cycle. These reactions occur in bacteria growing with alanine, serine and threonine.

The cultures utilizing these particular amino acids were depleted of ${ }^{15} \mathrm{~N}$ up to $12.9 \%$ relative to the initial composition of the substrate. Further evidence for the lack of direct incorporation without fractionation is given by Macko et al. (1983) in the direct analysis of individual amino acids. This isotopic fractionation could result from a combination of isotope discriminations in the uptake of the amino acid, deamination and utilization of an excess ammonia pool. No change in fractionation, however, was observed with the uptake of an increasing percentage of the substrate (up to $97.7 \%$ of the alanine); therefore, fractionation during uptake is minimal. To test isotopic fractionations during deamination, $V$. harveyi was cultured on $d$-alanine, the enantiomer of $l$-alanine. The $l$-alanine is the amino acid commonly found in proteins, whereas $d$-alanine occurs mainly in bacterial cell walls. Similar isotopic results were obtained in cultures grown on $l$-alanine and $d$ alanine, which must have been deaminated before entering the biochemical pathway.

The observed large negative isotope fractionation can be explained by two factors: (1) loss of ${ }^{15} \mathrm{~N}$ - 
enriched ammonia (pool C), and (2) fractionation of ammonia during glutamate synthesis (pool B) (Fig. 1). Firstly, loss of isotopically enriched ammonia during growth must occur in order to maintain an isotopic mass balance for the culture medium and the bacterial biomass. Excretion of ammonia has been observed in these and other cultures. The amount of excreted ammonia is dependent upon the ratio of the quantity of nitrogen needed for growth to the amount of amino acid that has been deaminated. From analyses of the amino acid left in the media, the amount of nitrogen (dry wt) contained in the cells, this ratio could be as low as 0.5 . Second, the amino acid deaminases are more reactive than glutamate dehydrogenase (Fig. 1), so an excess ammonia pool develops. The glutamate-synthesizing enzyme fractionates the nitrogen isotopes as it combines with ammonia to form glutamate.

No growth occurred on the medium without the added organic substrate. Nitrate was not utilized by $V$. harveyi in these experiments; the dry weight of cultures did not increase with the addition of nitrate, and the isotopic composition of the whole cells did not change appreciably with the presence of the nitrate in the medium (Table 1). In certain instances, notably with glutamate and tyrosine, appreciable differences were measured. A possible explanation for the change in $\delta^{15} \mathrm{~N}$ with added nitrate would be incomplete washing of the media from these particular cultures.

Cells utilizing aspartic or glutamic acid are able to channel these amino acids directly into the metabolic pathways without deamination, the remainder of the amino acids being synthesized by transamination (Macko et al., 1983). Bacteria grown on aspartic and glutamic acids were enriched in ${ }^{15} \mathrm{~N}$ relative to the substrate. Again, no isotope effect was observed with increased utilization of the substrate. Ammonia is lost when deamination of glutamic acid is necessary to produce organic acids for the generation of cellular energy. Only a portion of the substrate must be metabolized, as the carbon numbr of these two amino acids is high. An isotopic fractionation during deamination yields a ${ }^{15} \mathrm{~N}$-depleted pool of ammonia, which is excreted from the cell. An additional modification of the large isotope fractionation associated with glutamate and aspartate occurs as a result of the $\mathrm{C} / \mathrm{N}$ of these amino acids. More aspartate $(\mathrm{C} / \mathrm{N}$ $=4$ ) must be deaminated by the bacteria than glutamate $(\mathrm{C} / \mathrm{N}=5)$ for the derivation of a similar amount of cellular energy.

Smaller nitrogen isotope fractionations were observed in cultures grown on tyrosine, arginine, proline, glycine and $N$-acetylglucosamine. These amino acids enter the metabolism of the cells by a variety of pathways before entering the scheme in Fig. 1. Both cultures grown on tyrosine formed brown, nitrogen-rich substances that were suspected to have been polymers, possibly of excretion products. For this reason, whereas a large portion of the amino acid was removed from solution (over 95\%), most was not utilized in biosynthesis. Any material that was metabolized was utilized, and little isotope fractionation between amino acid and cell material

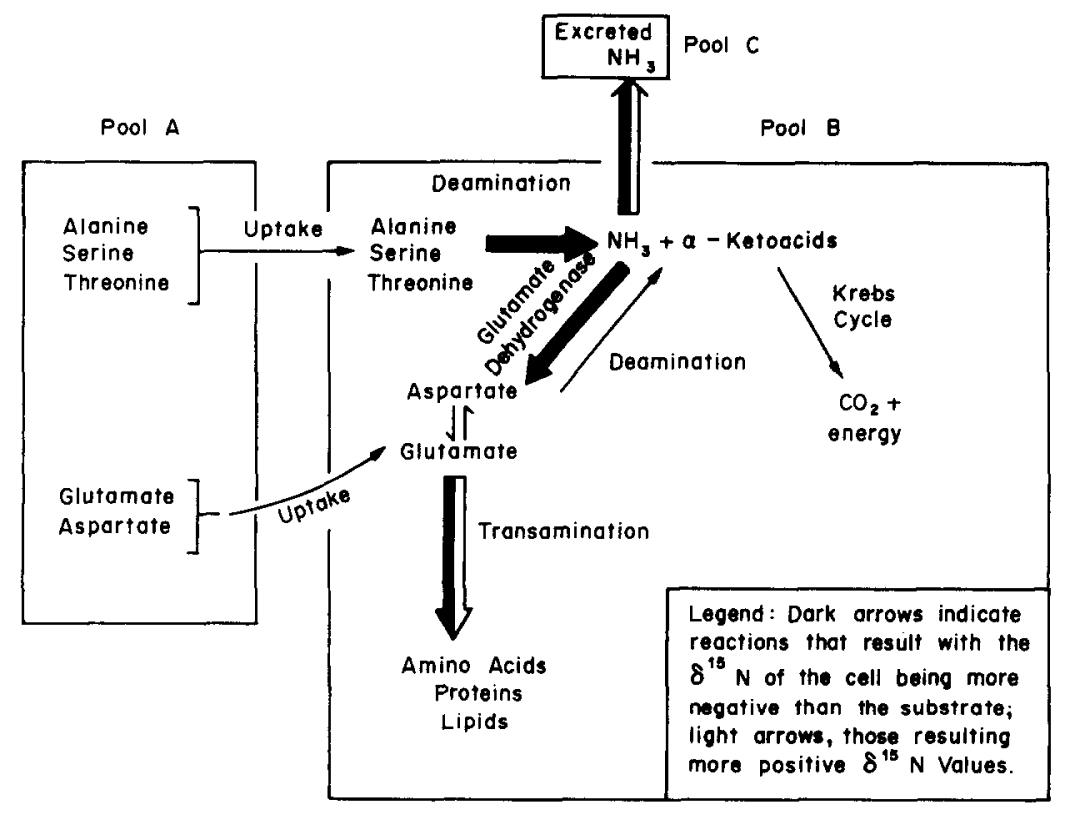

Fig. 1. Nitrogen metabolism in bacteria. Dark arrows indicate reactions that result in the $\delta^{1 .} \mathrm{N}$ of the cell being more negative than the substrate; light arrows, reactions that result in more positive $\delta^{15} \mathrm{~N}$ values. The arrows that are half dark and half light indicate reactions, which are key in determining the $\delta^{15} \mathrm{~N}$ of the cell. but the negative or positive shift in $\delta^{15} \mathrm{~N}$ depends upon preceding reactions. 
occurred. Similarly, proline, because of its ring structure and the relative inaccessibility of the nitrogen, had little associated fractionation. Nitrogen derived from this compound was probably used entirely.

The fractionation of arginine is more complex. The presence of four separate nitrogen atoms, almost certainly with different isotopic compositions, complicates the interpretation. Preferential deamination of lighter nitrogen atoms at the same position in the compound could also explain the observation. Furthermore, the low $\mathrm{C} / \mathrm{N}$ composition of arginine could produce an excess of nitrogen during cellular metabolism of this compound. Growth on glycine and $N$-acetylglucosamine was relatively slow compared with growth on the other amino acids. Bacteria metabolize the amino sugar by first cleaving off the acetyl group, then deaminating the sugar. Most of the ammonia is probably fixed into biosynthetic products, and little is excreted. Glycine uptake results in an oversupply of nitrogen to the cell relative to carbon $(\mathrm{C} / \mathrm{N}=2)$. Excretion of the large excess of nitrogen results. Glycine may be deaminated, or in some bacteria the amino group of glycine is transferred to glutamic acid via transamination (Moat, 1979).

Heterotrophic bacteria can change to a considerable extent the isotopic composition of organic matter. The $\delta^{13} \mathrm{C}$ and the $\delta^{15} \mathrm{~N}$ of micro-organisms are regulated by incorporation by the cell of the substrate into biosynthetic pathways, the $\mathrm{C} / \mathrm{N}$ of the substrate, and nitrogen loss as ammonia during growth and respiration. The results were obtained with one strain of one species of bacteria cultured on individual, pure compounds. In natural environments with species and substrate diversity, these large isotope fractionations could cancel each other and not be observed. In certain environments wherein the organic source material is heavily influenced by a particular compound (e.g. cellulose) or one microbial population dominated (e.g. anaerobic, highsulfur marine sediments), the isotopic composition of organic matter could be altered extensively before it is polymerized into microbiologically resistant humic acids and kerogen.

Acknowledgements-We thank P. E. Hare and T. C. Hoering for assistance with the amino acid and isotope ratio analyses, K. H. Nealson for the culture of Vibrio harveyi, and J. W. Farrington, A. P. Gize and T. C. Hoering for critical reviews of the manuscript. This research was supported in part by grants from the Charles E. Culpeper Foundation and the Charles A. Dana Foundation.

\section{REFERENCES}

Chambers L. A. and Trudinger P. A. (1979) Microbiological fractionation of stable sulfur isotopes: a review and critique. Geomicrobiol. J. 1, 249-293.

Estep M. F., Tabita F. R., Parker P. L. and Van Baalen C. (1978) Carbon isotope fractionation by ribulose-1.5bisphosphate carboxylase from various organisms. Plant Physiol. 61, 680-687.

Hare P. E. (1977) Subnanomole-range amino acid analysis. In Methods in Enzymology (Edited by Hirs C. H. W. and Timasheff S. N.), Vol. 47, Part E, pp. 3-18. Academic Press, New York.

Macko S. A. (1981) Stable nitrogen isotope ratios as tracers of organic geochemical processes. Ph.D. Thesis, The University of Texas at Austin, $181 \mathrm{pp}$.

Macko S. A., Estep M. L. F., Hare P. E. and Hoering T. C. (1983) Stable nitrogen and carbon isotopic composition of individual amino acids isolated from cultured microorganisms. Carnegie Inst. Wash. Yearbook 82, 404-410.

Macko S. A.. Estep M. L. F. and Hoering T. C. (1982) Nitrogen isotope fractionation by blue-green algae cultured in molecular nitrogen and nitrate. Carnegie Inst. Wash. Yearbook 81, 413-417.

Miyazaki T., Wada E. and Hattori A. (1980) Nitrogen isotope fractionation in the nitrate respiration by the marine bacterium Serratia marinoruba Geomicrobiol. J. 2, 115-126.

Moat A. G. (1979) Microbial Physiology, 600 pp. John Wiley. Chichester.

Nakai N. and Jensen M. L. (1964) The kinetic isotope effect in the bacterial reduction and oxidation of sulfur. Geochim. Cosmochim. Acta 28, 1893-1912.

Nealson K. H. (1978) Isolation, identification, and manipulation of luminous bacteria. In Methods in Enzymology (Edited by Deluca M. A.). Vol. 57, pp. 153-166. Academic Press, New York.

Van Baalen C. (1962) Studies on marine blue-green algae Bot. Mar. 4, 129-139. 